\title{
Effects of storage temperatures on the antioxidative activity and composition of yam
}

\author{
Su-Tze Chou ${ }^{\mathrm{a}}$, Been-Huang Chiang ${ }^{\mathrm{b}}$, Yun-Chin Chung ${ }^{\mathrm{a}}$, \\ Pei-Chun Chen ${ }^{c}$, Cheng-Kuang Hsu ${ }^{c, *}$ \\ ${ }^{a}$ Department of Food and Nutrition, Providence University, No. 200, Chungchi Road, Shalu, Taichung 433, Taiwan, ROC \\ ${ }^{\mathrm{b}}$ Graduate Institute of Food Science and Technology, National Taiwan University, No. 1, Sec. 4, Roosevelt Road, Taipei 106, Taiwan, ROC \\ ${ }^{\mathrm{c}}$ Department of Biotechnology and Bioinformatics, Asia University, No. 500, \\ Lioufeng Road, Wufeng Shiang, Taichung 413, Taiwan, ROC
}

Received 21 March 2005; received in revised form 15 June 2005; accepted 15 June 2005

\begin{abstract}
The effects of storage temperatures on the composition and antioxidative activities of one kind of Taiwanese yam tubers, Tainung No. 1 (TNG1) (Dioscorea alata), were investigated at room temperature $\left(20 \pm 8{ }^{\circ} \mathrm{C}\right), 17 \pm 2$ and $10 \pm 1.5^{\circ} \mathrm{C}$. Measurements of the antioxidative activities included reducing power and $\alpha, \alpha$-diphenyl- $\beta$-pricryl-hydrazyl radical-scavenging activity. The crude lipid and fibre contents decreased with storage time at all three temperatures, but the reducing sugar contents increased during storage. Both the reducing power and DPPH radical-scavenging activity of TNG1 decreased after 3 and 11 weeks at room temperature and $17{ }^{\circ} \mathrm{C}$, respectively. At $10^{\circ} \mathrm{C}$, significant decline in the reducing power was found after 14 weeks, while the DPPH radical-scavenging activity tended to increase after 7 weeks due to the microbes causing rottenness.
\end{abstract}

(C) 2005 Elsevier Ltd. All rights reserved.

Keywords: Yam; Storage temperature; Antioxidative activity; Composition

\section{Introduction}

Yam has been classified as one of the important staples in the diets of many tropical countries because of the carbohydrate it provides. For example, yam is widely grown in west Africa (Cooursey \& Haynes, 1970; Waitt, 1963). Some yams are also used as medicines in oriental countries to prevent diarrhea and diabetes (Hsu, Chen, Hsu, Chen, \& Chang, 1984; Yen, 1992); thus yams are considered to be helpful to human health. Yam (Dioscorea alata) has been suggested to have nutritional superiority when compared with other tropical root crops (Wanasundera \& Ravindran, 1994). Yam is composed mainly of starch (75-84\% of the dry weight)

\footnotetext{
${ }^{*}$ Corresponding author. Tel.: +886 4 23323456; fax: 886423337010.

E-mail address: ckhsu@asia.edu.tw (C.-K. Hsu).
}

with small amounts of proteins, lipids and most vitamins and is very rich in minerals (Lasztity, Hidvegi, \& Bata, 1998; Omonigho, 1988). The average crude protein content of seven yam cultivars was $7.4 \%$, which was higher than those reported for other tropical roots, and the protein from yam also showed a better amino acid balance for human nutrition (Baquar \& Oke, 1976; Bradbury, 1988; Marcus et al., 1998).

Modern researches have shown that yam extracts can reduce blood sugar (Hikino et al., 1986; Undie \& Akubue, 1986) and blood lipid (Araghiniknam, Chung, NelsonWhite, Eskelson, \& Watson, 1996), inhibit microbe activity (Hu et al., 1999; Hu, Dong, Yao, Kobayashi, \& Iwasaki, 1996; Kelmanson, Jager, \& Van Staden, 2000) and show antioxidative activity (Chan, Hsu, Wang, \& Su, 2004 Farombi, Britton, \& Emerole, 2000;). Farombi et al. (2000) demonstrated that brown yam flour 
contained natural antioxidants and might mitigate damage and diseases caused by oxidative components. Chen, Chang, and Wang (2002) reported that D. alata L. Var. purpurea (M.) Pouch. (Purpurea), one kind of Taiwanese yam tuber, exerted trophic effects in the cecum by mediating luminal fermentation. Fang and Kong (2002) found that yam (Dioscrea japonica) could enhance serum IgG concentrations and promote splinic lymphocyte proliferation. The active components of yam include steroidal sapogenin, glycan and polyphenol oxidase. Diosgenin, extracted from Dioscorea species, is a natural steroidal sapogenin used as a precursor in the industrial synthesis of steroids. Araghiniknam et al. (1996) found the steroid extract from yam significantly reduced serum lipid peroxidation, lowered serum triglyceride and phospholipid levels, and increased high density lipid level in older humans. Discorin, the storage protein of yam tuber, was reported to have scavenging activity toward 1,1-diphenyl-2-picrylhydrazyl (DPPH) radical. Dioscoran, a glycan isolated from $D$. japonica, was shown to markedly inhibit the hypoglycemic affects in normal and alloxan-induced hyperglycemic mice (Hikino et al., 1986).

The effect of storage on the composition, appearance, and physical properties of yam has been investigated (Afoakwa \& Sefa-Dedeh, 2001, 2002a, 2002b; Sefa-Dedeh \& Afoakwa, 2002; Treche \& Agbor-Egbe, 1996). In this study, the storage effect on the composition and antioxidative activities of one kind of Taiwanese yam tubers stored at room temperature, 17 and $10{ }^{\circ} \mathrm{C}$, were determined. We decided to work on this yam species because our previous data (Chiang, Chou, \& Hsu, 2005) indicated that it had the highest antioxidative activity among five common Taiwanese yam cultivars.

\section{Materials and methods}

\subsection{Chemicals and materials}

$\alpha, \alpha$-Diphenyl- $\beta$-pricryl-hydrazyl (DPPH), gallic acid, and $\alpha$-tocopherol ( $\alpha$-Toc) were purchased from Sigma Chemicals Co. (St. Louis, MO, USA). Tainung No. 1 (TNG1) yam ( $D$. alata), within one week after harvest, was purchased from a farmer in Mingjian Shiang, Nantou county, Taiwan. The yam was stored at three temperatures until sampling; they were: room temperature $\left(20 \pm 8{ }^{\circ} \mathrm{C}\right), 17 \pm 2$ and $10 \pm 1.5^{\circ} \mathrm{C}$.

\subsection{Weight loss and germination/rottenness}

The weights and appearances of 12 randomly selected yams stored at each temperature were recorded during storage. Data for the appearance observations were reported as the percentage of the number of rotten or germinal yams out of twelve.

\subsection{Composition determination}

The analysis of the protein, lipid, moisture, ash, and fibre contents of TNG1 was performed according to standard AOAC methods (AOAC, 1984). The method for determining the reducing sugar content was based on Hariprakash and Nambisan (1996). The crude mucus content was measured according to the method reported by Tsai and Tai (1984). Sliced yam tubers were homogenized and extracted with 3 volumes of $0.1 \% \mathrm{NaHSO}_{3}$ solution and then centrifuged at $10,000 \mathrm{~g}\left(0^{\circ} \mathrm{C}\right)$ for $30 \mathrm{~min}$. The extracts were precipitated with 3 volumes of acetone. After centrifugation at $2500 \mathrm{~g}$ for $10 \mathrm{~min}$, the precipitate was dissolved in water, dialyzed against distilled water and then centrifuged at $10,000 \mathrm{~g}\left(0^{\circ} \mathrm{C}\right)$ for $30 \mathrm{~min}$. The supernatant was precipitated with 3 volumes of acetone and centrifuged at $2500 \mathrm{~g}$ for $10 \mathrm{~min}$. The final precipitate was dried in vacuum and weighed.

\subsection{Measurement of DPPH radical-scavenging activity}

Yam DPPH radical-scavenging activity was measured according to the method of Yamaguchi, Takamura, Matoba, and Terao (1998). The samples were blended with $50 \%$ ethanol, and then its aliquot of the mixture (100 $\mu \mathrm{l}, 200 \mathrm{mg}$ sample/ml of $50 \%$ ethanol) was further mixed with $100 \mathrm{mM}$ Tris $-\mathrm{HCl}$ buffer ( $400 \mu \mathrm{l}, \mathrm{pH} 7.4)$ and then added to $1 \mathrm{ml}$ of $500 \mu \mathrm{M}$ DPPH in ethanol (final concentration of $250 \mu \mathrm{M}$ ). The mixture was shaken vigorously and left in the dark at room temperature for $20 \mathrm{~min}$. The absorbance of the resulting solution was measured spectrophometrically at $517 \mathrm{~nm}$. $\alpha$-Toc $(0.04-1.25 \mathrm{mg} / \mathrm{ml})$ was used as the standard for the calibration curve, and the DPPH radical-scavenging activities were expressed as $\mu$ mole $\alpha$-Toc equivalents per gramme of tested dry samples.

\subsection{Measurement of reducing power}

The reducing power of the yam extracts was determined according to the method of Yen and Chen (1995). The extract $(0.16-10.0 \mathrm{mg} / \mathrm{ml})$ was mixed with an equal volume of $0.2 \mathrm{M}$ phosphate buffer $(\mathrm{pH}$ 6.6) and $1 \%$ potassium ferricyanide, and then incubated at $50{ }^{\circ} \mathrm{C}$ for $20 \mathrm{~min}$. An equal volume of $1 \%$ trichloroacetic acid was added to the mixture to stop the reaction, and then the mixture was centrifuged at $2500 \mathrm{~g}$ for $10 \mathrm{~min}$. The supernatant was mixed with distilled water and $0.1 \% \mathrm{FeCl}_{3}$ at a ratio $1: 1: 2$, and then the absorbance were measured at $700 \mathrm{~nm}$. The reducing powers of the tested samples increased with the absorbance values. Gallic acid was used as the standard for the calibration curve, and the reducing powers were expressed as mg gallic acid equivalents per gramme of tested dry sample. 


\subsection{Statistical analysis}

One-way analysis of variance (one-way ANOVA) was conducted using a package (SAS Institute Inc., Cary, NC). Duncan's multiple range test was used to determine the significant difference between different treatments.

\section{Results and discussion}

\subsection{Weight loss and appearance changes}

The effects of storage temperatures on the weight loss of Tainung No. 1 (TNG1) are shown in Fig. 1. After 16 weeks, the weight losses were $9.21 \%, 2.42 \%$ and $5.82 \%$ at room temperature, 17 and $10{ }^{\circ} \mathrm{C}$, respectively. During a 16-week period, the changes of the weight losses at 17 and $10^{\circ} \mathrm{C}$ were linear. For TNG1 stored at room temperature, linear weight loss was observed during a 12week period, and then non-linear weight loss was found as storage time longer than 12 weeks. It was noted that the weight loss at $17^{\circ} \mathrm{C}$ was lower than that at $10^{\circ} \mathrm{C}$ because the relative humidity of the air at $17^{\circ} \mathrm{C}(65 \pm 7 \%)$ was higher than that at $10^{\circ} \mathrm{C}(54 \pm 5 \%)$. Treche and $\mathrm{Ag}$ bor-Egbe (1996) reported that weight losses of two yam cultivars were about $31-35 \%$ at room temperature for 110 days. Wang and Liu (1992) reported that weight losses of TNG1, stored at $20 \pm 8, \quad 17 \pm 1$ and $14 \pm 1{ }^{\circ} \mathrm{C}$ for 10 weeks, were $11.5 \%, 4.6 \%$ and $3.2 \%$, respectively. As showing in Fig. 2, chill storage at 17 and $10^{\circ} \mathrm{C}$ successfully delayed the germination of TNG1; however, storage at $10^{\circ} \mathrm{C}$ created a significant rottenness problem after 12 weeks. Wang and Liu (1992) also reported that 17 and $14{ }^{\circ} \mathrm{C}$ storages could reduce the germination of TNG1 and prolong its shelf life, and $14{ }^{\circ} \mathrm{C}$ also caused the yam to become putrid. Since the germination for TNG1 stored at room temperature started at 12 weeks, germination might be the cause of the non-linear weight loss. The results indicated that $17^{\circ} \mathrm{C}$ was a better storage temperature for yam in terms of weight loss and appearance considerations.

\subsection{Effect of storage on the composition}

Table 1 shows the effect of storage temperature on the composition of TNG1 stored at room temperature, 17 and $10{ }^{\circ} \mathrm{C}$ for two months. It was found that there were no significant changes in the ash, crude protein and mucus contents of TNG1 during storage. However, storage did decrease the lipid and crude fibre contents.

\subsection{Effect of storage on the antioxidative activities}

In the reducing power assay, the presence of reductants (antioxidants) in the samples would result in the reduction of the $\mathrm{Fe}^{3+}$ /ferricyanide complex to its ferrous form. Amount of $\mathrm{Fe}^{2+}$ complex can then be monitored by measuring the formation of Perl's prussian blue at $700 \mathrm{~nm}$. The effect of storage on the reducing power of TNG1 stored at room temperature, 17 and $10^{\circ} \mathrm{C}$ is shown in Fig. 3. Significant variation in the reducing power of TNG1 was found and the variation might be due to sample variation. Compared to the initial value at 0 week, significant decline of the reducing power started at 3,11 and 14 weeks for TNG1 stored at room temperature, 17 and $10{ }^{\circ} \mathrm{C}$, respectively. The results indicated that chill storage delayed the decrease of the reducing power. The protonradical-scavenging action is known to be an important mechanism of antioxidation. Fig. 4 shows the effect of storage on the DPPH radical-scavenging activity of TNG1. Similar to the reducing power, significant decline of the DPPH radical-scavenging activity also started at 3 , and 11 weeks for TNG1 stored at room temperature and

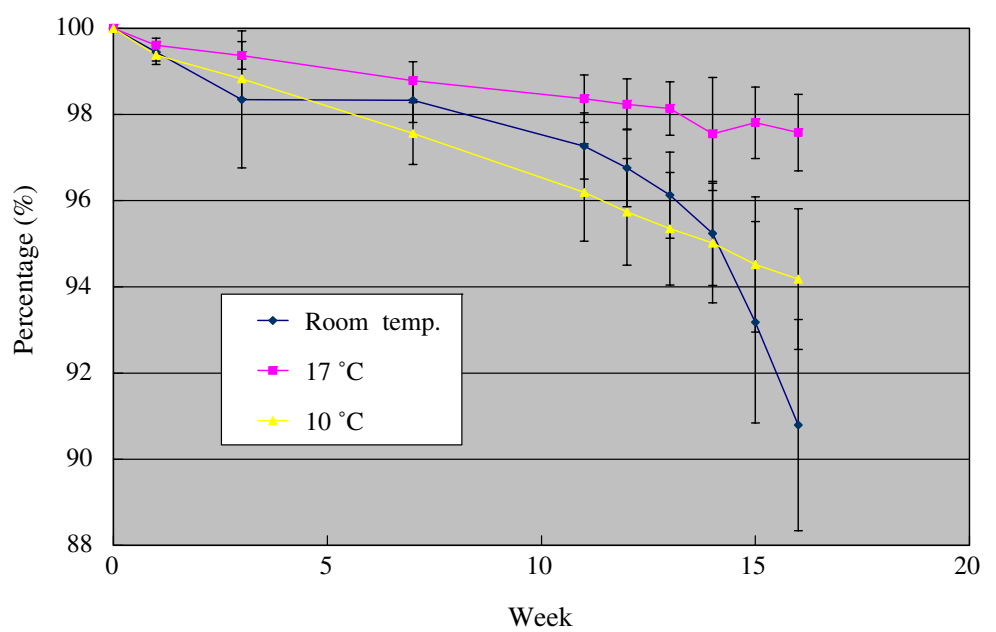

Fig. 1. Effects of storage on the weight losses of TNG1 stored at room temperature, 17 and $10^{\circ} \mathrm{C}$. 


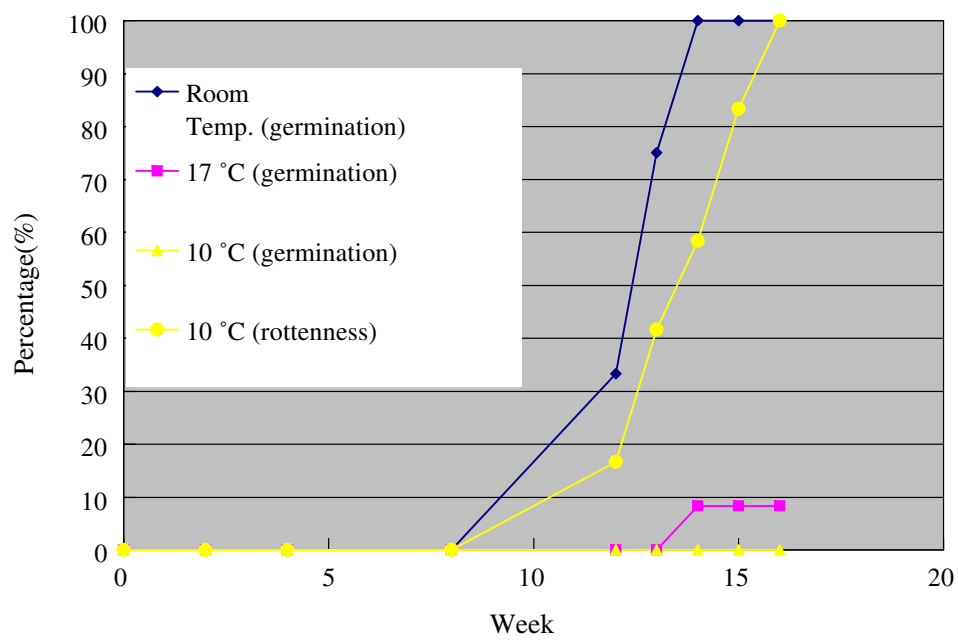

Fig. 2. Effects of storage on the germination and rottenness of TNG1 stored at room temperature, 17 and $10{ }^{\circ} \mathrm{C}$.

Table 1

The effects of storage on the composition of yam stored at room temperature, 17 and $10{ }^{\circ} \mathrm{C}$

\begin{tabular}{|c|c|c|c|c|c|c|c|}
\hline Month & Temperature & Moisture (\%) & Ash (\%) & Protein $(\%)$ & Lipid (\%) & Mucus (\%) & Crude fibre $(\%)$ \\
\hline 0 & & $75.5 \pm 0.1^{\mathrm{bc}}$ & $1.12 \pm 0.04^{\mathrm{A}}$ & $2.58 \pm 0.35^{\mathrm{A}}$ & $0.075 \pm 0.008^{\mathrm{a}}$ & $3.10 \pm 0.15^{\mathrm{A}}$ & $2.52 \pm 0.34^{\mathrm{a}}$ \\
\hline 1 & $\begin{array}{l}\text { Room temperature } \\
17^{\circ} \mathrm{C} \\
10^{\circ} \mathrm{C}\end{array}$ & $\begin{array}{l}76.3 \pm 0.5^{\mathrm{b}} \\
72.5 \pm 0.4^{\mathrm{d}} \\
78.3 \pm 0.7^{\mathrm{a}}\end{array}$ & $\begin{array}{l}1.18 \pm 0.03 \\
1.27 \pm 0.01 \\
1.20 \pm 0.01\end{array}$ & $\begin{array}{l}2.70 \pm 0.11 \\
2.68 \pm 0.03 \\
2.73 \pm 0.02\end{array}$ & $\begin{array}{l}0.061 \pm 0.007^{\mathrm{b}} \\
0.078 \pm 0.012^{\mathrm{a}} \\
0.058 \pm 0.006^{\mathrm{b}}\end{array}$ & $\begin{array}{l}3.01 \pm 0.17 \\
3.43 \pm 0.27 \\
3.38 \pm 0.27\end{array}$ & $\begin{array}{l}1.71 \pm 0.05^{\mathrm{b}} \\
1.45 \pm 0.11^{\mathrm{c}} \\
1.77 \pm 0.03^{\mathrm{b}}\end{array}$ \\
\hline 2 & $\begin{array}{l}\text { Room temperature } \\
17^{\circ} \mathrm{C} \\
10^{\circ} \mathrm{C}\end{array}$ & $\begin{array}{l}75.0 \pm 0.8^{\mathrm{c}} \\
73.1 \pm 0.3^{\mathrm{d}} \\
74.8 \pm 1.2^{\mathrm{c}}\end{array}$ & $\begin{array}{l}1.04 \pm 0.06 \\
1.10 \pm 0.04 \\
1.03 \pm 0.05\end{array}$ & $\begin{array}{l}2.41 \pm 0.06 \\
2.33 \pm 0.15 \\
2.61 \pm 0.11\end{array}$ & $\begin{array}{l}0.037 \pm 0.005^{\mathrm{c}} \\
0.035 \pm 0.004^{\mathrm{c}} \\
0.029 \pm 0.001^{\mathrm{c}}\end{array}$ & $\begin{array}{l}3.65 \pm 0.24 \\
3.15 \pm 0.71 \\
3.46 \pm 0.25\end{array}$ & $\begin{array}{l}1.32 \pm 0.23^{\mathrm{c}} \\
1.28 \pm 0.17^{\mathrm{c}} \\
1.30 \pm 0.10^{\mathrm{c}}\end{array}$ \\
\hline
\end{tabular}

The values are means \pm standard deviation.

Values in the same column followed by different superscripts are significantly different $(p<0.05)$.

A Values in the same column are not significantly different.

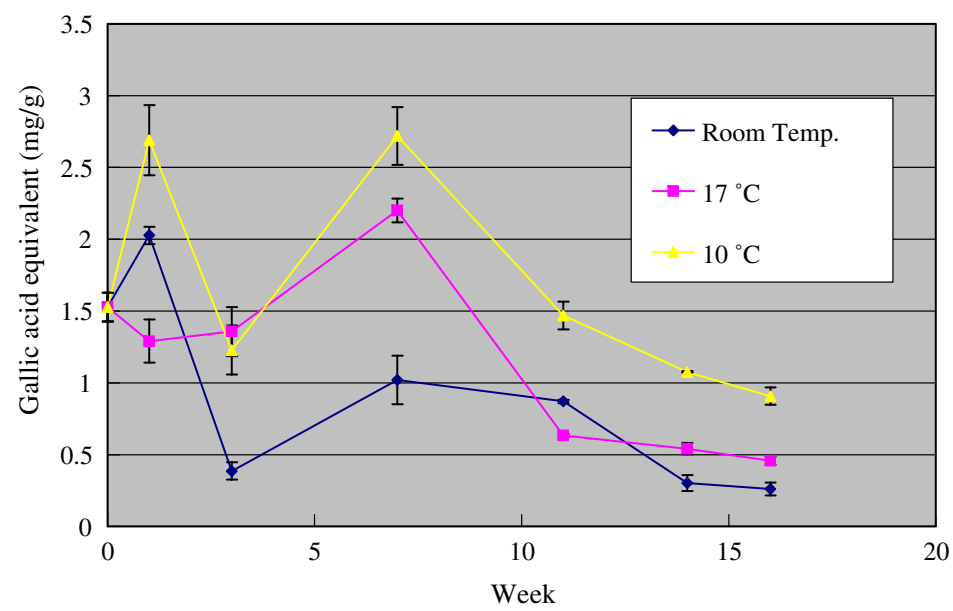

Fig. 3. Effects of storage on the reducing power of TNG1 stored at room temperature, 17 and $10{ }^{\circ} \mathrm{C}$.

$17^{\circ} \mathrm{C}$, respectively. It was found that the correlation coefficient between the DPPH scavenging activity and reducing power, at both room temperature and $17^{\circ} \mathrm{C}$, was 0.90 ; a combination of the two temperatures showed a correlation coefficient of 0.88 (Fig. 5). The results indicated a good correlation between the DPPH'-scavenging activity and reducing power. However, at $10{ }^{\circ} \mathrm{C}$ the DPPH radical-scavenging activity showed extremely different behaviour. Compared to the initial value at week 0 , the DPPH radical-scavenging activity of TNG1 stored at $10^{\circ} \mathrm{C}$ decreased at 3 weeks and then increased at 7, 11 and 14 weeks (Fig. 4). Since the rottenness of TNG1 stored at 


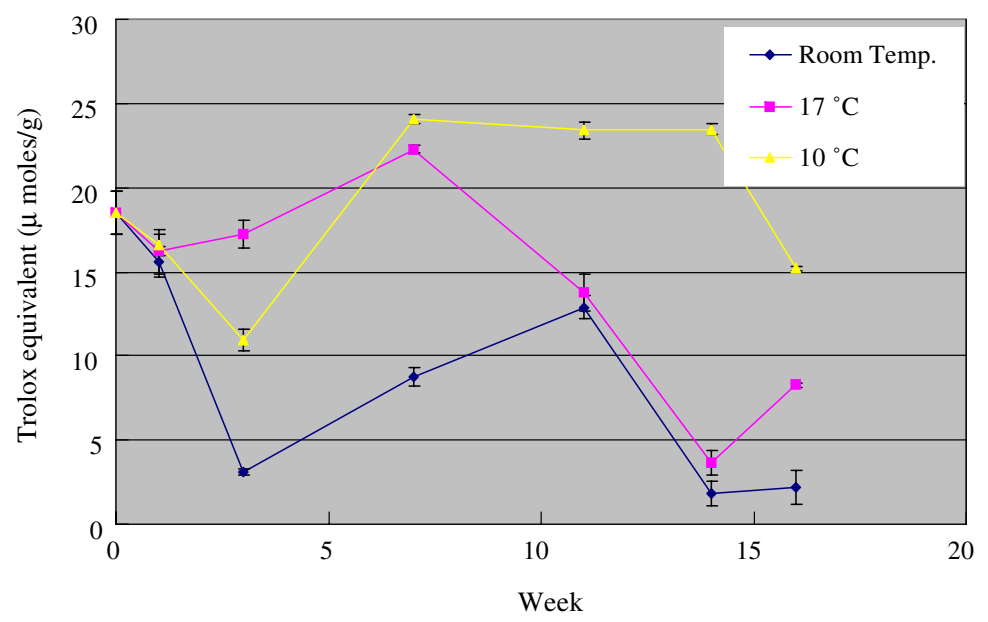

Fig. 4. Effects of storage on the DPPH radical-scavenging activity of TNG1 stored at room temperature, 17 and $10{ }^{\circ} \mathrm{C}$.

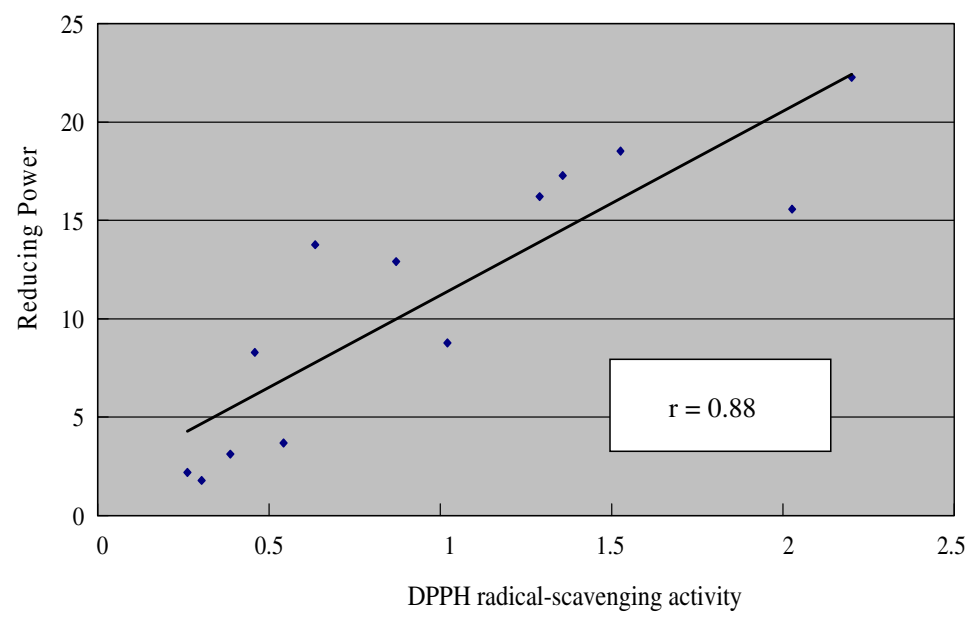

Fig. 5. Correlation between the reducing power and DPPH radical-scavenging activity of TNG1 stored at room temperature and $17^{\circ} \mathrm{C}$.

$10{ }^{\circ} \mathrm{C}$ started sometime between 8 and 12 weeks, it was suggested that the increase of DPPH radical-scavenging activity at $10{ }^{\circ} \mathrm{C}$ was due to the rottenness. It was possible that the metabolites from the microbes causing the rottenness of TNG1 also contributed to DPPH radical-scavenging activity.

\section{Conclusion}

Significant weight loss due to germination was observed in TNG1 stored at room temperature for 12 weeks. Chill storage at $17^{\circ} \mathrm{C}$ delayed and reduced the germination and no germination occurred at $10^{\circ} \mathrm{C}$ during four months of storage. However, storage at $10^{\circ} \mathrm{C}$ caused significant rottenness after 12 weeks of storage. Regardless of the storage temperatures, the crude lipid and fibre contents decreased with storage time, but the reducing sugar contents increased during storage. Significant declines in both the reducing power and DPPH radical-scavenging activity were found in TNG1 after
3 and 11 weeks of storage at room temperature and $17^{\circ} \mathrm{C}$, respectively. At $10^{\circ} \mathrm{C}$, no significant reduction in the reducing power was found until 14 weeks, while the DPPH radical-scavenging activity tended to increase after 7 weeks due to the microbes causing the rottenness.

\section{Acknowledgement}

This study was supported by the National Science Council (NSC 91-2313-B-468-001), Taiwan, ROC.

\section{References}

Afoakwa, E. O., \& Sefa-Dedeh, S. (2001). Chemical composition and quality changes occurring in Dioscorea dumetorum pax tubers after harvest. Food Chemistry, 75, 85-91.

Afoakwa, E. O., \& Sefa-Dedeh, S. (2002a). Textural and microstructural changes associated with post-harvest hardening of trifoliate yam (Dioscorea dumetorum) pax tubers. Food Chemistry, 77, 279-284. 
Afoakwa, E. O., \& Sefa-Dedeh, S. (2002b). Changes in rheological properties and amylase activities of trifoliate yam, Dioscorea dumetorum, starch after harvest. Food Chemistry, 77, 285-291.

AOAC (1984). Official methods of analysis of the association of official analytical chemists (14th ed.). Washington, DC: AOAC.

Araghiniknam, M., Chung, S., Nelson-White, T., Eskelson, C., \& Watson, R. R. (1996). Antioxidant activity of dioscorea and dehydroepiandrosterone (DHEA) in older humans. Life Science, 59, PL147-157.

Baquar, S. R., \& Oke, O. L. (1976). Protein in Nigerian yams (Dioscorea spp.). Nutrient Reports International, 14, 237-248.

Bradbury, J. H. (1988). The chemical composition of tropical root crops. ASEAN (Association of South East Asian Nations) Food Journal, 4, 3-13.

Chan, Y. C., Hsu, C. K., Wang, M. F., \& Su, T. Y. (2004). A diet containing yam reduces the cognitive deterioration and brain lipid peroxidation in mice with senescence accelerated. International Journal of Food Science and Technology, 39(1), 99-107.

Chen, H. L., Chang, C. T., \& Wang, C. H. (2002). The trophic effects of Taiwanese Yam (Dioscorea spp.) tubers on the epithelial cells in the lower gut of mice. Health Food Society of Taiwan, 68.

Chiang, B. H., Chou, S. T.,\& Hsu, C. K. (2005). Yam affects the antioxidative and gel-forming properties of surimi gels. Journal of the Science of Food and Agriculture (in press).

Cooursey, D. G., \& Haynes, P. H. (1970). Root crops and their potential as in the tropics. World Crops, 22, 261-265.

Fang, M. C., \& Kong, R. L. (2002). Immuno-bioactive of yam crude polysaccharide and yam yogurt in cell culture and mice. Health Food Society of Taiwan, 66.

Farombi, E. O., Britton, G., \& Emerole, G. O. (2000). Evaluation of the antioxidant activity and partial characterization of extracts from browned yam flour diet. Food Research International, 33, 493-499.

Hariprakash, C. S., \& Nambisan, B. (1996). Carbohydrate metabolism during dormancy and sprouting in yam (Dioscorea) tubers: changes in carbohydrate constituents in yam (Dioscorea) tubers during dormancy and sprouting. Journal of Agricultural and Food Chemistry, 44, 3066-3069.

Hikino, H., Konno, C., Takahashi, M., Murakami, M., Kato, Y., Karikura, M., et al. (1986). Isolation and hypoglycemic activity of dioscorans A, B, C, D, E, and F; glycans of Dioscorea japonica rhizophors. Planta Medica, 3, 168-171.

Hsu, H. Y., Chen, Y. P., Hsu, S. J., Chen, J. J., \& Chang, S. C. (1984). Essentials of materia medica. Taipei: New Medicine and Pharmacy press.

Hu, K., Dong, A., Yao, X., Kobayashi, H., Iwasaki, S., \& Jing, Y. K. (1999). A new pregnane from Dioscorea collettii var. hypoglauca. Journal of Natural Products, 62, 299-301.
Hu, K., Dong, A., Yao, X., Kobayashi, H., \& Iwasaki, S. (1996). Antineopastic agents: I. Three spirostanol glycosides from rhizomes of Dioscorea collettii var. hypoglauca. Planta Medica, 62, $573-575$.

Kelmanson, J. E., Jager, A. K., \& Van Staden, J. (2000). Zulu medicinal plants with antibacterial activity. Journal of Ethnoparmacology, 69, 241-246.

Lasztity, R., Hidvegi, M., \& Bata, A. (1998). Saponins in food. Food Reviews International, 14(4), 371-390.

Marcus, D. L., Thomas, C., Rodriguez, C., Simberkoff, K., Tasi, J. S., Strfaci, J. A., et al. (1998). Increased peroxideratoin and reduced antioxidant enzyme activity in Alzheimer's disease. Experimental Neurology, 150, 40-44.

Omonigho, S. E. (1988). Deterioration of pounded yam and its shelf life extension (p. 162), MS Thesis. University of Benin, Benin City, Nigeria.

Sefa-Dedeh, S., \& Afoakwa, E. O. (2002). Biochemical and textural changes in trifoliate yam Dioscorea dumetorum tubers after harvest. Food Chemistry, 79, 27-40.

Treche, S., \& Agbor-Egbe, T. (1996). Biochemical changes occurring during growth and storage of two yam species. International Journal of Food Science and Nutrition, 47, 93-102.

Tsai, S. S., \& Tai, F. J. (1984). Studies on the mucilage from tuber of yam (Dioscorea alata Linn.) I. Isolation and purification of the mucilage. Journal of the Chinese Agricultural Chemical Society, 22(1-2), 88-94.

Undie, A. S., \& Akubue, P. I. (1986). Pharmacological evaluation of Dioscorea dumetorum tuber used in traditional antidiabetic therapy. Journal of Ethnopharmacology, 15, 133-144.

Waitt, A. W. (1963). Yam: Dioscorea species. Field Crop Abstract, 16(3), 145-157.

Wanasundera, J. P. D., \& Ravindran, G. (1994). Nutrition assessment of yam (Dioscorea alata) tubers. Plant Foods for Human Nutrition, 46, 33-39.

Wang, J. Y., \& Liu, S. Y. (1992). Studies on the tuber storage of three yam (Dioscorea alata L.) genotypes. Journal of Agricultural Research of China, 41(2), 159-168.

Yamaguchi, T., Takamura, H., Matoba, T., \& Terao, J. (1998). HPLC method for evaluation of the free radical-scavenging activity of foods by using 1,1,-dipheny-1-2-picrylhydrazyl. Bioscience Biotechnology and Biochemistry, 62, 1201-1204.

Yen, K. Y. (1992). The illustrated chinese materia medica (p. 84). Taipei: SMC Publishing Inc.

Yen, G. C., \& Chen, H. Y. (1995). Antioxidant activity of various tea extracts in relation to their antimutagenicity. Journal of Agricultural and Food Chemistry, 43(1), 27-32. 